\title{
Uma sociedade juxta jotum naturare ou um corporativismo incompleto? ${ }^{1}$
}

\author{
Jessie Jane Vieira de Sousa
}

\begin{abstract}
"A ação católica é a tática mais moderna da Igreja para partir à conquista da Idade Nova. É a organização das suas milícias, compenetradas todas da responsabilidade de sua grave missão. E é o emprego de métodos delicadíssimos de atuação social, por infiltração direta em toda linha, em vez do ataque em massa e em linha com o Estado e a Política”. ${ }^{2}$
\end{abstract}

Esse texto insere-se em uma pesquisa desenvolvida ao longo dos últimos anos, cujo objetivo central foi o entendimento das estratégias elaboradas pela Igreja Católica, através do catolicismo social, na busca de novos papéis a serem exercidos na sociedade capitalista contemporânea.

Esta busca centrou-se inicialmente sobre a política social da Igreja, nos princípios e na dinâmica de sua relação com o Estado e, sobretudo, na construção e no exercício de um determinado discurso sobre o trabalho urbano a partir do final do século XIX, e como tal discurso se expressou no Brasil entre os anos de 1930 a 1964.

O enfoque foi direcionado para uma das diversas possibilidades de pesquisa apresentadas por este catolicismo social, os Círculos Operários Católicos, experiência corporificadora da forma católica hierárquica de intervenção junto ao mundo do trabalho no Brasil entre os anos 30 a $64 .^{3}$

Neste momento pretendemos apresentar, numa perspectiva comparada, de que maneira o corporativismo católico, uma das principais características do catolicismo social, se apresentou no Brasil e quais as suas convergências/divergências com o corporativismo presente em Portugal, na ${ }^{4}$ Espanha ${ }^{5}$ Itália entre os anos de 1930 a 1940. Contudo, faz-se necessário precisar que foi com a encíclica Quadragesimo anno, promulgada em 15 de março de 1931 por Pio XI, cujo papado ocorreu durante o período entre as duas grandes guerras, que o corporativismo foi introduzido no debate do catolicismo social. 
Naquele contexto, o corporativismo surgiu como uma resposta às novas inquietações dos católicos envolvidos na ação social e foi visto por estes como a possibilidade de a Igreja se fazer presente no mundo de então. Era preciso que os católicos se pronunciassem sobre a restauração da ordem social e seu aperfeiçoamento em conformidade com o evangelho.

É o que fez o papa Pio XI, ao trazer soluçōes concretas que transcendiam o problema da classe trabalhadora. Ele tentou se afastar do liberalismo e do coletivismo, constituindo o núcleo do solidarismo, escola filosófica que tanto influenciou a encíclica Quadragesimo anno. Esta encíclica aborda a questão da propriedade sob um enfoque diferente daquele realizado pela encíclica Rerum novarum, quando propõe um equilíbrio, na sua dimensão individual e social, entre capital e trabalho.

A leitura do social presente neste texto pontifício também se baseia na visão de que, com a queda do Antigo Regime, foram introduzidas diversas reformas institucionais que envolvem Estado, associações e corporações, modelo de concorrência e mercado, causando decadência nos costumes. Daí o aguçamento do egoísmo, responsável por todos os males, já que...

Existiu efetivamente, em outros tempos, uma ordem social que, embora não sendo perfeita nem completa em todos os seus pontos, dadas as circunstâncias e necessidades da época, estava de certo modo conforme com a razão correta. ${ }^{6}$

A preocupação do papado de Pio XI voltava-se para o relacionamento entre Estado e Igreja, e era vista como insubstituível para o preenchimento do vazio existente na relação entre os indivíduos e o Estado. Para a Igreja, esta relação deveria ser feita por meio das associações, não importando quais fossem.

Em relação às associações, a encíclica deu mais importância àquelas de cunho socioeconômico. Com isto afastou-se do sindicalismo clássico para se aproximar do sindicalismo corporativo, que, acentuando os interesses comuns entre operários e patróes e demonstrando grande empenho no sentido de que a sociedade fosse organizada sob outro critério, voltado para a harmonização dos interesses, propunha também que se abandonasse o critério econômico, e o substituísse pelo social, com ênfase sobre a atividade profissional onde cada um funcionasse e na qual coincidissem patrôes e operários. 
Para que tal sociedade fosse possível era necessário criar as ordines ordens ou ramos - nos quais "os homens se enquadrassem não de acordo com a categoria que se lhes atribui no mercado de trabalho, mas sim em conformidade com a função social que cada um desempenhasse".7

O projeto era organizar os agentes produtivos em colégios ou corporações, com absoluta liberdade quanto a sua fundação, adstrição e funcionamento, posto que eram associações de direito privado. Uma organização social que buscava superar os impasses do liberalismo e do socialismo no tocante à luta de classes, propondo uma 'terceira via' baseada no princípio da harmonia entre as classes. Tal proposta recebeu grande acolhida diante da conjuntura de crise do capitalismo e de rejeição ao socialismo, que marcou o período entre as duas grandes guerras. É neste contexto que podemos entender a simpatia de Roma por Mussolini que, a partir de 1923 a 1926, com o Pacto do Palazzo Chigi e o do Palazzo Vidoni, em 1925 , inicia a montagem do aparato jurídico do corporativismo fascista. ${ }^{8}$

$\mathrm{Na}$ encíclica Quadragesimo anno aparece, pela primeira vez, a reivindicação por justiça social - apesar do uso freqüente que se fazia do termo - que buscava estabelecer uma ordem jurídica e social que se contrapusesse ao projeto social liberal e que garantisse uma eqüitativa distribuição da renda produzida. Não mais se tratava de uma justiça cumulativa como fora proposta pelo papa Leão XIII, que se limitara a regular as relaçōes individuais, sem, no entanto, contemplar os fenômenos globais da vida socioeconômica.

Pio XI propunha algo mais radical: reformar as instituições como elemento prioritário no afã de restaurar a ordem social através da moderação cristã, que pudesse estabelecer um justo equilíbrio entre meios e fins, subordinando toda a atividade criadora ao único fim supremo que é Deus - e a caridade, complemento necessário à moderação e à justiça, com a função de unir os homens e abrir caminho para a esperança. Criou um método de reflexão com base na filosofia natural, e em um projeto a ser executado pela Ação Católica - organização que personificava uma nova forma de ser da Igreja na sociedade, por meio da militância apostólica.

Enfim, Pio XI propunha princípios norteadores da restauração da sociedade, calcados na caridade cristã e na justiça social, que seriam exercidos sob o manto do corporativismo. Todavia, entendemos que o corpora- 
tivismo católico não se confunde com o corporativismo estatal, ou dirigista, muito embora ambos tenham em comum forte apelo disciplinador assumido pelos setores conservadores, quando a emergência da questão social é tomada fundamentalmente como uma questão de trabalho.

\section{Corporativismo 'tradicional'}

Segundo Ludovico Incisa, ${ }^{9}$ o corporativismo é uma doutrina que propugna pela organização da coletividade que se funda na associação representativa dos interesses e das atividades profissionais baseadas nas corporações, que, por sua vez, se apóiam na solidariedade orgânica dos interesses concretos e das colaborações daí decorrentes. Para Manoilescu, ${ }^{10}$ o principal teórico do corporativismo, todas as sociedades históricas foram corporativas, menos as sociedades democráticas nascidas no século XIX, porque a Revolução Francesa destruiu os quadros corporativos e reduziu a sociedade aos indivíduos.

A formulação teórica do corporativismo baseou-se na experiência da comuna medieval italiana, que monopolizava o direito ao exercício profissional e, conseqüentemente, a produção, constituindo assim canais obrigatórios de representação política. Este sistema estava pautado na autonomia semi-soberana das categorias e nas relações paternalistas existentes entre mestres e aprendizes. Tal modelo pressupunha relaçôes sociais de tipo tradicional.

Com a Revolução Industrial estas relações ruíram. A industrialização, para se realizar, exigiu a ruptura com os padróes corporativos até então hegemônicos, exatamente por serem considerados incompatíveis com as inovações tecnológicas. As novas formas de organização do trabalho serão agora delineadas no conflito de interesses e na luta de classes expressa pelo sindicalismo.

Por sua vez, o corporativismo se apresentará como forma oposta ao modelo sindical, que será o gestor do conflito gerado nas sociedades industrializadas ou em vias de desenvolvimento. $\mathrm{O}$ modelo corporativo defende a colaboração entre as classes no âmbito das categorias, porque a sua "interpretação da dialética social é otimista, ao passo que as premissas em que se baseia o modelo sindical são conflitantes". ${ }^{11}$ 
Como já dito, politicamente o modelo corporativo se apresentará como alternativa ao modelo democrático-liberal, na medida em que propõe uma democracia orgânica onde os indivíduos serão portadores de interesses precisos e identificáveis. Nesta dimensão, o corporativismo foi tomado como defensor da ordem político-econômica e, portanto, mais aceitável, já que pôde ser um fator importante na concentração do sistema e aliado na destruição das forças contrárias a esta proposta, isto é, as forças classistas e ideológicas.

Todavia, os teóricos do corporativismo católico ${ }^{12}$ não são unânimes quanto a esta questão, pois sobrevivem desconfianças em relação à sociedade industrial e permanece certa nostalgia em relação a:

(...) uma sociedade descentralizada, baseada nos corpos intermediários, que vão da família à sociedade local e à associação profissional, e trazem ao indivíduo remédio para a sua solidão, assegurando-lhe, em um quadro pluralista, dentro de um equilíbrio de poderes e oposiçóes, um mais profundo sentido de participação política. ${ }^{13}$

Portanto, podemos apontar a existência de um corporativismo 'contra-revolucionário', ou tradicional, e de um corporativismo 'dirigista'. $\mathrm{O}$ corporativismo tradicional, ou contra-revolucionário, como já foi sugerido, nasce do protesto contra a Revolução Industrial e contra a Revolução Francesa, e inspira-se nos fundamentos legitimistas dos católicos, que,

(...) à margem da modernização política e econômica, tentam encontrar, por meio de articulações solidárias, a união com todos os excluídos do sistema: as categorias subalternas. Antiliberal, o corporativismo se apresenta como contestação absoluta do sistema, como um ideal restaurador. ${ }^{14}$

Os teóricos deste corporativismo tradicional querem a reconstrução orgânica e hierárquica da sociedade, tornando-se este um tema recorrente na doutrina social católica. Este projeto já estava presente nos primeiros documentos pontifícios dedicados ao problema social. Leão XIII, na Quod Apostolici Muneris, de 1878, deixava claro este desejo, ao afirmar que:

(...) Torna-se oportuno favorecer as sociedades artesanais e operárias que, ao amparo da Religião, habituam seus sócios a manterem-se contentes com a sua sorte, a suportarem com merecimento a fadiga e a levarem uma vida sempre quieta e tranqüila. ${ }^{15}$ 
Na encíclica Rerum novarum, de 1892, o mesmo Pontífice advoga o modelo corporativo, mas o define de forma menos nostálgica, ao afirmar que na solução da questão operária devem colaborar os capitalistas e os operários. E devem fazê-lo como "instituições ordenadas a oferecer oportuna ajuda aos necessitados e a aproximar e unir as duas classes entre si”. ${ }^{16}$

Estas reflexões de Leão XIII tornaram-se objeto de intensas discussões no interior da Igreja através de Congressos ${ }^{17}$ e círculos de estudos, até que, por fim, os frutos destes debates foram sistematizados pelo sociólogo católico Giuseppe Toniolo.

Leão XIII havia indicado duas vias para solução daquilo que foi chamado pelos católicos de 'questão social'. Uma possibilidade, mais próxima do corporativismo clássico, baseava-se na associação entre empregados e patrões numa mesma categoria. A outra possibilidade seria a associação somente de empregados ou de patrões, o que terminou prevalecendo diante da pressão do sindicalismo já existente. Contudo, a união tornou-se uma meta a ser alcançada através das associações de base, tais como os Círculos Operários. De qualquer forma, os católicos terminaram aceitando de fato a existência da luta de classes, mas permaneceram afirmando a necessidade da sua subordinação ao bem comum.

Nesta aceitação do modelo sindical está implícito o reconhecimento do modelo representativo e, conseqüentemente, da democracia representativa. A partir de então, o princípio da união entre as classes se mantém como aspecto importante nos movimentos de inspiração católica e se projeta mais na ação ideológica e política do que na sindical ou social. Esta inflexão se deu no período do primeiro pós-guerra, quando o Partido Popular italiano passou a reivindicar a presença, na Câmara de Representantes, das chamadas classes organizadas, o que, segundo os católicos de então, mantinha o caráter classista dos sindicatos. Esta orientação manteve-se no movimento católico, no segundo pós-guerra.

Todavia, mesmo abandonado pela corrente tradicionalista e restauradora do movimento católico, o corporativismo continuou sendo defendido pela corrente conservadora, que incorporava setores monárquicos como a Action Française, o carlismo espanhol - a Comunión Tradicionalista -, e esteve presente no conservadorismo salazarista e na Espanha de Franco. 


\section{Corporativismo católico numa perspectiva comparada}

Neste trabalho interessa-nos entender como este corporativismo católico se apresentou no Brasil e quais as suas convergências/divergências com o corporativismo presente na Europa no período citado. ${ }^{18}$

Contudo, o corporativismo, como contraposição ao pluralismo, tem sido uma categoria explicativa recorrente na historiografia sobre a América Latina dos anos 30 e $40 .{ }^{19} \mathrm{O}$ debate sobre a questão vem se renovando em torno de três correntes, quais sejam: a político-culturalista, a societária e a estruturalista. ${ }^{20}$

Interessa-me mais especificamente a primeira vertente, por se debruçar sobre as características católicas presentes em tal corporativismo, no plano político-cultural, isto é, na consideração do:

(...) corporativismo latino-americano como produto de uma longa tradição político-cultural ibero-romano, que tem suas raízes nas instituiçōes medievais da península ibérica e na tradição legal romana.

O expoente desta corrente é Howard Wiarda, para quem o corporativismo devia ser tomado em dois sentidos diferentes: o primeiro se refere aos regimes ou experiências sociais manifestamente corporativas, nos anos 30-40, definidos pelo seu sistema de autoridade e de representação de interesses, oriundo principalmente do pensamento social católico, que prezava a representação funcional, a integração do trabalho e do capital, formando uma cadeia de unidades ordenadas hierarquicamente e exercendo o monopólio da harmonia garantida funcionalmente pelo Estado. ${ }^{21}$

O segundo, mais abrangente, representava determinada tradição histórico-cultural ibero-latina, que se expressava em uma forma dominante de organização sócio-política hierárquica, elitista, autoritária, burocrática, patrimonialista, católica e corporativa. ${ }^{22}$

Wiarda pretendia explicar, de um lado, a ideologia e as instituiçōes cuja aparição ou persistência poderia ser analisada em diferentes contextos históricos e, de outro, "a variável explicativa que corresponde a uma determinada tradição político-cultural católica organicista.". ${ }^{23}$

Como já vimos, este corporativismo, analisado historicamente, deve ser tomado como expressão de uma tradição histórica que remonta à lei 
canônica e romana, à tradição tomista, ao sistema de guildas e associações profissionais e às características patrimonialistas do Estado do século XVI. Surgiu como uma maneira de lidar com a 'questão social', que passava pela absorção dos trabalhadores pelo alto, repetindo um modelo social forjado durante séculos pela sociedade ibero-americana. ${ }^{24}$

Para os autores que trabalharam nesta perspectiva, ${ }^{25} \mathrm{o}$ mais instigante é o fato de que tais tendências tenham sobrevivido por tantos séculos. Eles tomaram a persistência do padrão e das estruturas corporativas como demonstração de sua infinita permeabilidade às mudanças e de sua imensa capacidade de adaptar-se à modernidade e à industrialização do século XX.

Em que pese todas as objeções teóricas ${ }^{26}$ colocadas a respeito desta abordagem, cremos que ela pode nos apontar possibilidades quanto à análise do corporativismo católico que, em linhas gerais, foi incorporado pelo Estado brasileiro. Acreditamos que a profunda influência operada pelo catolicismo em nossa formação político-cultural está informada por aquilo que a historiografia tem consagrado como corporativismo, e que o próprio Wiarda assinalou como sendo uma "montagem incompleta do corporativismo".

De qualquer forma, resta precisar o significado de tal questão para o catolicismo e para a constituição do aparato jurídico-político que disciplinou o mundo do trabalho no Brasil.

Contudo, o corporativismo católico é extremamente multifacetado. Podemos, via de regra, enquadrá-lo como sendo contra-revolucionário ou tradicional, porque renasceu contra as conseqüências econômicas e políticas da Revolução Industrial, mas não se transformou em protesto contra todo o sistema engendrado por ela. ${ }^{27}$ Foi um movimento que propôs uma restauração orgânica e hierárquica da sociedade, se contrapondo ao industrialismo. $^{28}$

Era a expressão política de uma proposta doutrinária onde a organização da sociedade deveria se pautar na associação representativa dos interesses e das atividades profissionais. A partir da solidariedade básica que redundaria dessa organização, seria possível construir elementos que harmonizassem tal sociedade.

Os católicos difundiram tal proposta, isto é, a reconstrução orgânica e hierárquica da sociedade, desde 1878, quando Leão XIII, na Encíclica Quod Apostolici Muneris, afirmou: 
(...) Torna-se oportuno favorecer as sociedades artesanais e operárias que, ao amparo da Religião, habituam seus sócios a manterem-se contentes com a sorte, a suportarem com merecimento a fadiga e a levarem uma vida sempre quieta e tranqüila. ${ }^{29}$

Após o refluxo da linha tradicionalista e restauradora do movimento católico, tais ideais corporativos foram mantidos pelos legitimistas conservadores envolvidos em lutas políticas de cunho monárquico, como o carlismo, na Espanha; a Action Française; em Portugal, nos tempos de Salazar, ${ }^{30}$ e na Espanha de Franco.

$\mathrm{Na}$ Espanha, o termo corporação não foi utilizado, mas aceitou-se o princípio dos sindicatos mistos (presentes na Rerum Novarum, de Leão XIII); em Portugal, o corporativismo funcionou no contexto de uma política antiindustrial. Porém, nestes dois países, logo que políticas de desenvolvimento industrial foram implementadas, o corporativismo foi sendo gradualmente fragmentado. ${ }^{31}$

Para Phillipe Schmitter, ${ }^{32}$ o Estado Novo português foi um laboratório da experiência corporativa, tanto como invenção de um imaginário legitimador da refundação nacional, quanto como maneira de integrar as classes trabalhadoras sob um regime ditatorial. Esta experiência tornou-se ainda mais significativa, na medida em que apontou para caminhos diferentes da experiência italiana, com a radicalização do fascismo, e da alemã, com o nacional-socialismo.

O caso português foi exemplar para a direita católica conservadora e pelos maurrasianos do período entre as duas guerras mundiais. Era para estes setores a possibilidade da construção de uma terceira via, projeto embalado pelos católicos desde finais do século XIX. Para o autor em tela, o corporativismo português foi parte integrante de uma 'modernidade nostálgica' ancorada nos valores de um passado considerado moderno.

Todavia, é necessário distinguir o corporativismo católico do corporativismo dirigista (estatal), que teve sua concretização no corporativismo fascista. Tal distinção está na perspectiva ética do primeiro: 'a supremacia do amor e do bem comum sobre os interesses particulares', isto é, numa moral assentada no conceito de justiça, na caridade e no bem comum. Já para o segundo, os interesses que deviam prevalecer eram os da nação, onde os 
problemas sociais são gerados, sobretudo, pela necessidade de implementação da riqueza e da produção nacional e não de sua distribuição. ${ }^{33}$

Ainda analisando o caso português, Maria Inácia Rezola afirma:

(...) que o movimento operário católico naquele país nasceu no início dos anos 30, num período de institucionalização do Estado Novo e do estabelecimento de um novo quadro nas relaçóes entre este e a Igreja, ao surgirem então, no seio desta, elementos socialmente motivados e empenhados na constituição de organizações operárias, segundo as encíclicas sociais de Leão XIII, Rerum Novarum (1891), e de Pio XI, Quadragesimo Anno (1931) e Divino Redemptori (1937). ${ }^{34}$

Prossegue a autora, dizendo que tais

(...) documentos papais consideravam a ação sindical necessária à defesa dos direitos econômicos legítimos dos operários e ao aperfeiçoamento da ordem social, embora o sindicalismo católico fosse apenas um meio para a organização da sociedade segundo o modelo corporativo cristão, alternativo ao individualismo liberal e ao coletivismo socialista. ${ }^{35}$

A despeito do compromisso existente entre o Estado e a Igreja, quando da promulgação do Código do Trabalho Nacional, parte do clero português manifestou-se de forma crítica sobre o que foi entendido como coerção das liberdades associativas através do corporativismo estatal. E propunham como alternativa um corporativismo cristão. Dentre os que se manifestaram estava o padre Boaventura de Almeida, dirigente nacional da Ação Católica, organismo voltado para a formação de leigos católicos, e que, em 1935, irá formar a União Nacional Católica, embrião da Liga Operária Católica e do Secretariado Econômico-Social, dedicado à formação crítica dos católicos diante do corporativismo estatal. ${ }^{36}$

A pauta reivindicatória destes católicos era:

1- Fim da miséria material, através da repartição da riqueza e da rejeição tanto da luta de classes como da livre concorrência;

2 - Fim da miséria social com respeito social aos operários por parte dos patrôes e do Estado;

3 - Fim da miséria intelectual com a obrigatoriedade do ensino e proibição do trabalho infantil; 
4 - Fim da miséria moral através da recristianização da classe operária e com a dignificação do trabalho.

O próprio Mussolini, ao apresentar ao Conselho Nacional das Corporações, em 1933, a regulamentação sobre as corporações, salientou tal característica:

(...) como instrumento que, sob a égide do Estado, torna real a disciplina integral, orgânica e unitária das forças produtivas, com vistas ao desenvolvimento da riqueza, do poder político, e do bem-estar do povo italiano. ${ }^{37}$

O corporativismo fascista apresentava-se, pois, como resultante da conciliação do corporativismo com a industrialização, onde a unificação e a organização das forças produtivas deviam ser garantidas. ${ }^{38}$

Michael Hall, analisando as diferenças entre a experiência corporativa brasileira e a italiana, afirma que o corporativismo italiano exprimiu os anseios e ressentimentos da pequena burguesia e emergiu das lutas entre as várias facções do mesmo regime, isto é, entre antigos sindicalistas revolucionários, liderados por Edmondo Rossoni, que representaram um papel importante no estabelecimento dos sindicatos fascistas. ${ }^{39}$ Hall afirma ainda que:

uma ampla violência praticamente eliminou os sindicatos socialistas e católicos. Rossano reivindicava a criação dos sindicatos integrais que incluiriam trabalhadores e empregadores na mesma entidade corporativa. ${ }^{40}$

A Carta del Lavoro, divulgada em 1927, se caracteriza por ser apenas uma declaração de princípios e não um código do trabalho, como foram o português, o espanhol e o brasileiro. É um documento contraditório, com trinta artigos impregnados pela doutrina social católica. ${ }^{41}$ Apesar desta presença doutrinária do catolicismo social, convém ressaltar que, na realidade, quem controlava amplamente o sistema era o partido fascista que, por sua vez, também exercia funções legais no que dizia respeito ao mundo do trabalho.

Donde se infere que não há como falar de sistemas corporativos católicos plenamente constituídos na Espanha, em Portugal. E o que foi implantado na Itália deve ser classificado sob uma ótica não católica. 


\section{Conclusão}

No Brasil, para Luiz Werneck Vianna, o corporativismo seria uma resposta às pressōes sociais sem, no entanto, ser a única solução possível para a resolução destes mesmos conflitos. Representava uma condenação à participação do governo no sistema produtivo como meio de resolver a crise econômica; apresentava características oriundas da sua adequação à ideologia revolucionária e seria voltado especialmente para os conflitos gerados no setor urbano-fabril, com controle sobre a classe operária vista como capaz de desestabilizar a paz social. ${ }^{42}$

Para os católicos brasileiros, herdeiros dos traços marcadamente tradicionalistas do catolicismo social, a palavra corporação apresentava um conteúdo ideológico significativo, por referir-se a uma experiência histórica vivida na corporação medieval destruída no século XVIII, "depois de haver dado durante cinco séculos a solução essencial para o problema econômico". 43

Contudo, mesmo lamentando a derrocada daquela sociedade e desejando a restauração da profissão organizada, não pretendiam que este modelo fosse implantado integralmente, porque tal sistema corporativo fora "afogado nas ondas implacáveis da Revolução Francesa". ${ }^{44}$

O papel que a Igreja se propôs a desempenhar na sociedade brasileira deste período, através da Ação Católica e dos Círculos Operários Católicos, e em sintonia com o Estado, era o de agente animador de um projeto social integral baseado na idéia de 'organização das classes':

(...) tem por fim primário a defesa da classe e de seus sócios, podendo visar secundariamente serviços de mutualismo e cooperativismo e mesmo de assistência social. Aos princípios do esforço próprio e da solidariedade acresce o da justiça a ser definido na vida do trabalho. ${ }^{45}$

Entre nós, foram estes traços 'secundários', como assistência social, mutualismo e cooperativismo, que marcaram a Ação Católica. Contudo, o papel de implementar uma legislação social e previdenciária não pode ser absolutamente ignorado, já que seu projeto pareceu expressar, em todos os princípios e objetivos, o desejo de forjar uma cultura corporativa, tanto no plano da organização das classes quanto na elaboração de um corpo jurídico voltado para a solução da chamada 'questão social'. 
Idealizou construir uma sociedade organizada a partir de associações profissionais (sindicatos e corporaçôes) que fossem capazes de agregar todos os trabalhadores de uma mesma categoria, visando, sobretudo, os interesses dos sócios relativos à mesma profissão: "para os operários: os salários, o horário, as condições de higiene e o tratamento, a garantia no trabalho, seguro contra acidente". ${ }^{46}$

Entre os anos de 1930 e 1940, no Brasil, as forças católicas, aglutinadas pela revista $A$ Ordem, e operando através dos órgãos da Ação Católica, em especial os Círculos Operários, trabalharam na perspectiva da construção de um catolicismo triunfante, que pretendia dominar o campo da educação, da política e até mesmo da economia. Seu projeto visava construir uma neocristandade, isto é, estabelecer uma nova hegemonia na sociedade brasileira através da relação da Igreja com o Estado na sociedade.

Para tanto, a constituição de 'organismos corporativos' foi tratada como uma necessidade surgida da própria natureza humana:

(...) fundada sobre corpos profissionais, a sociedade humana acha-se em estado de estrutura natural. Fundada sobre classes inimigas, acha-se num estado violento, instável e duvidoso. ${ }^{47}$

Para os católicos, o estado natural da sociedade humana funda-se nos corpos profissionais, como órgãos da sociedade civil onde os conflitos sociais são ordenados e disciplinados, porque o princípio de união que liga entre si os membros da mesma profissão encontra-se na produção dos bens e na prestação de serviços, frutos de sua atividade comum. ${ }^{48}$

A união se daria em função dos interesses comuns desenvolvidos no conjunto das profissões, onde o cumprimento dos deveres e direitos recíprocos visaria o bem comum da profissão e da sociedade. A coordenação deste movimento estaria a cargo de uma autoridade que surgisse no seio da própria profissão, cabendo a ela editar regulamentos e administrar os serviços da profissão. Acima desta autoridade estaria a justiça social que, por sua vez, iria requerer uma organização interprofissional a ser estabelecida no plano regional, nacional e até mesmo internacional. Por outro lado,

(...) a organização profissional deve aliviar o Estado das inúmeras tarefas que, atualmente, pesam sobre ele, mas sem absorvê-lo ou enfraquecê-lo, pelo contrário, aperfeiçoando-o e fortalecendo-o. ${ }^{49}$ 
Nesta perspectiva, os corpos profissionais organizados priorizariam a aglutinação dos corpos similares e criariam, ao menos, duas federações: a dos ofícios manuais e a das carreiras liberais. Reuniriam corporações e federaçôes sob uma autoridade profissional suprema; integrariam essa autoridade suprema no estatuto da nação e atingiriam, assim, o ponto culminante a que tende a organização corporativa e em que ela se deve completar. $^{50}$

A proposta era de uma organização profissional verticalizada e pouco plural, na medida em que a centralidade se encontrasse justamente no princípio da federalização. Por outro lado, acrescenta que:

(...) a organização corporativa não está, em si, ligada a forma alguma de governo ou de Estado determinado. Ao contrário, assim como na ordem política, as diversas formas de governo são legítimas desde que concorram para o bem comum, assim também, na ordem profissional, as formas da organização corporativa são, em condições idênticas, deixadas à preferência dos próprios interessados. ${ }^{51}$

A Igreja reconhecia a possibilidade das múltiplas formas de organização corporativa, porque seu fundamento não estava na estrutura, mas na maneira como lidaria com as principais tarefas que deveriam ser desempenhadas, sendo a principal aquela relacionada com a formação profissional dos seus membros, e não dependeria, essencialmente, do Estado para realizá-la. Caberia também à organização corporativa garantir aos empregadores e empregados a liberdade de manifestação, assim como a cada parte a possibilidade de deliberar, separadamente, a fim de salvaguardar os interesses legítimos, prevenidos os abusos que a superioridade de uma parte cometeria sobre a outra. ${ }^{52}$

A expectativa dos católicos era de que a organização corporativa de todos os corpos profissionais, a partir dos seus princípios, pudesse gerir os interesses divergentes em função do bem comum, porque seriam instituições baseadas nos princípios da justiça social, onde cada grupo exerceria um papel subsidiário, não podendo enfraquecer a atividade daqueles que "estão em plano inferior".

Partindo do pressuposto de que "a lei natural" exige que os recursos terrestres "transformados pelo trabalho em capitais sejam postos à disposi- 
ção das necessidades humanas de maneira ordenada”, os católicos organizaram um decálogo, onde cada item da vida econômica moderna foi analisado e definido do ponto de vista da justiça e da caridade cristã.

Defenderam o princípio da propriedade privada; o direito de herança como estritamente relacionado com o direito à propriedade; a nacionalização de empresas; as convenções coletivas de trabalho, onde os sindicatos de empregados e empregadores estabeleceriam vínculos permanentes; a co-gestão das empresas; a greve, que deveria ser arbitrada pela justiça, o salário-mínimo, abonos familiares e seguros sociais. Enfim, defenderam plenamente a Convenção Coletiva do Trabalho.

É sugestivo o fato de Confederação Nacional dos Operários Cristãos ter publicado o Código Social exatamente em 1942, ano em que o Estado consolidou a legislação trabalhista e organizou a Justiça do Trabalho. E, ao fazê-lo, distinguia os sindicatos das associações profissionais estruturadas de forma corporativa. A profissão compreende todos aqueles que cooperam no exercício da mesma, sejam eles empregados ou empregadores, devendo a política social colocar todos os cuidados na reconstituição dos corpos profissionais, visando reagrupar os homens segundo os ramos de sua atividade e não segundo o lugar que ocupam no mercado de trabalho. ${ }^{53}$

A identidade do corporativismo católico com os diversos corporativismos estatais, vigentes nos anos 1930, também pode ser analisada a partir da tese defendida por Romano, em que Estado e Igreja se identificaram na busca de uma ação disciplinadora sobre o mercado de trabalho. ${ }^{54}$ Esse desejo comum fez com que convergissem os interesses de um e de outro contra a democracia leiga e contra os movimentos operários que não se encontravam sob a tutela de ambos, o que nos remete àquilo que Gomes assinalou, ao analisar a contribuição de Oliveira Vianna e Alceu Amoroso Lima para a montagem do corporativismo católico, como resultante da ação destas duas instituições, isto é, a Igreja operando uma verdadeira espiritualização das relaçôes de classe, e o Estado se impondo na supervisão e coordenação destas relações. ${ }^{55}$

Romano como que arrematou a questão, ao analisar o processo vivido pela Igreja na superação do discurso corporativista, ou, pelo menos, daquele corporativismo identificado com os regimes totalitários: 
(...) a extrema abstração dos seus princípios políticos, unida a um poder de projetar figuras concretas de unidade das consciências, permitiu ao catolicismo não se desorientar em compromissos de circunstâncias. Empenhouse, ao contrário, a longo prazo, através da educação e da cultura de massas, por instalar-se na 'consciência do Povo. ${ }^{56}$

Tal capacidade permitiu à Igreja sobreviver sem máculas àqueles regimes corporativos que ela havia cantado em prosa e verso. A sua enorme plasticidade política em face das instituições lhe possibilitou construir um novo discurso, restabelecendo a diferença entre essência e existência, entre autoridade em si e tal como aparece, onde o controle vertical da sociedade seria o fim bom e desejável, enquanto o totalitarismo deveria ser negado. ${ }^{57}$

Este é, em linhas gerais, o arcabouço do que poderíamos chamar de uma discussão preliminar sobre corporativismo católico e como a partir destes traços a Igreja estabeleceu suas relações com o Estado e com os trabalhadores urbanos nos anos 1930 e 1940.

Acreditamos que sejam questôes profundamente relevantes para a produção historiográfica brasileira, já que se torna cada vez mais evidente a incorporação de elementos da cultura católica em nossa formação político-cultural.

\section{Notas}

${ }^{1}$ Uma sociedade naturalmente justa, expressão usada por René Fulop Miler. Leão XIII e o nosso tempo. Potência da Igreja. Poder do mundo. 2. ed. Porto Alegre, 1941.

${ }^{2}$ LIMA, Alceu Amoroso. Pesten aetatis nostrae laicismum (1932). In: Pela Ação Católica. Rio de Janeiro. Biblioteca Anchieta, 1935. p. 162. Grifo meu.

${ }^{3}$ SOUSA, Jessie Jane Vieira de Sousa. Círculos Operários. Igreja Católica e o mundo do trabalho no Brasil. Rio de Janeiro: Editora da UFR, 2002.

${ }^{4}$ VOLOVITH, Marie-Chistine. O le mouvement catholique au Portugal à la fin de la Monarchie Constitucionnale (1891-1913). Paris: Sorbone Nouvelle (Paris III), Tese de Doctorat de 3éme Cycle, 1983; O fascismo em Portugal, Actas do Colóquio realizado na Faculdade de Letras de Lisboa em março de 1980; a Regra do Jogo (Biblioteca de História), 1982; SALAZAR, Oliveira. Como se levanta um Estado. Lisboa: Golden Books, 1977; FERRO, Antônio. Salazar, Le Porutugal et son chef (précedé d'une note sur l'idée de dictature pour Paul Valéry). Paris: Grasset, 1934; Cartilha Corporativa, Lisboa, Ediçōes da União Nacional, no 7 . Aniversário de publicação do Estatuto do Trabalho Nacional; LUCENA, Manuel de. A evolução do sistema corporativo português. Lisboa: Perspectivas e Realidades, 1986. 
${ }^{5}$ CASTILLO, Juan José. El sindicalismo amarillo en España: aportación al estudio del catolicismo social spañol (1912-1923). Madrid: Edicusa Editorial, 1977. (Cuadernos para el dialogo). ${ }^{6} \mathrm{PIO}$ XI, papa. Quadragesimo anno - Sobre a restauração e aperfeiçoamento da ordem social. Juiz de Fora: Lar Católico, 1944.

${ }^{7}$ Ibid., p. 83.

${ }^{8}$ Em 1922 Mussolini chega ao poder e introduz aos poucos o sistema corporativo: em 1926 reconhece apenas o direito dos sindicatos fascistas; em 1927 promulga a Carta del Lavoro; em 1928, a Câmara dos Deputados transformou-se em Câmara das Corporações.

${ }^{9}$ INCISA, Ludovico. In: Dicionário de política. Bobbio, Norberto; Nicola Matteuci e Giofranco Pasquino. Traduzido por Carmem C. Varriale ( et al). $7^{\circ}$ ed. Brasília, DF: UNB, 1995, p. 286-291.

${ }^{10}$ MONOILESCO, Mihail. O século do corporativismo. Rio de Janeiro: José Olympio, 1938.

${ }^{11}$ INCISA, Ludovico, op. cit, p. 287.

${ }^{12}$ Entre eles estão Ozanam, Lê Play, De Mun, La Tour du Pin, Hittze, padre Luigi Tparelli d'Azeglio, entre outros.

${ }^{13}$ INCISA, Ludovico, op. cit, p. 289.

${ }^{14}$ Ibid. p. 288.

15 Ibid.

16 Ibid.

${ }^{17}$ Como o de Vicenza ocorrido em 1892.

${ }^{18} \mathrm{O}$ corporativismo tem sido um componente central de diferentes regimes autoritários e fascistas, particularmente nos países latinos. Como prática ou ideologia, tem sido analisado como elemento essencial no debate sobre a natureza destes regimes tanto na Europa quanto na América Latina. Sobre esta questão ver: O’DONELL, Guillermo. O corporativismo e a questão do Estado. DCP. Belo Horizonte, 1076 (3).

${ }^{19}$ Hobsbawn, analisando Vargas e Perón à luz do fascismo europeu, afirma que, enquanto o fascismo destruiu os movimentos operários, os líderes latino-americanos os inspiraram. Ver, HOBSBAWN, Eric. A era dos extremos. São Paulo: Paz e Terra, 1997.

${ }^{20}$ ARAÚJO, Ângela M e TAPIA, Jorge R. B. Corporativismo e neo-corporativismo: o exame de duas trajetórias. BIB, Rio de Janeiro, n. 32, Segundo semestre de 1991. p. 3-130.

${ }^{21}$ Ibid.

22 Ibid.

${ }^{23}$ Ibid.

${ }^{24}$ Ibid.

${ }^{25}$ Esta concepção tem sido acusada de montar uma armadilha culturalista em torno da qual as sociedades ibero-americanas estariam amarradas a um corporativismo societal, o que as impossibilita de forjarem uma política cultural pluralista. 
${ }^{26}$ Tais objeções baseiam-se nas seguintes questões: 1-Como explicar a existência de padrōes tão diferentes de representação na Escandinávia, na região mediterrânea, na Ásia, no Oriente Médio e nos países latinos? 2- Como explicar a falta de corporativismo em países latinos de tradição católica, como é o caso da Colômbia? 3- Continuidade cultural torna-se uma explicação frágil quando se busca entender as novas formas de corporativismo existentes na atualidade, os chamados neo-corporativismos; 4- E, finalmente, a aceitação acrítica de um projeto de 'desenvolvimento de terceira via' sem que se corra o risco de tomar o discurso ideológico como verdade. A respeito da América Latina, ver: STEPEN, A. Estado, corporativismo e autoritarismo. Rio de Janeiro: Paz e Terra, 1980 / O'DONNELL, Guillermo. Acerca del 'corporativismo' y la question del Estado. Buenos Aires: Documento Cedeg e Clasco. n. 2, 1982.

${ }^{27}$ INCISA, Ludovico. In: Dicionário de política. Organizado por Norberto Bobbio. Traduzido por Carmem C. Varriale et al . 7 ed. Brasília, DF: UNB, 1995.

${ }^{28}$ Concepções de Ozanam, Le Play, De Mun, La Tour du Pin, Keteller e outros notórios católicos sociais do final do século XIX.

${ }^{29}$ INCISA, Ludovico. op. cit. p. 288.

${ }^{30}$ REZOLA, Maria Inácia. O sindicalismo católico no Estado Novo. 1931-1948. Lisboa: Editorial Estampa, 1999.

${ }^{31}$ MARTINHO, Francisco Carlos Palomanes. A bem da nação. O sindicalismo português entre a tradição e a modernidade (1933-1940). Rio de Janeiro: Civilização Brasileira/ FAPERJ, 2002.

32 SCHMITTER, Philippe C. Portugal. Do autoritarismo à democracia. Lisboa: Imprensa de Ciencias Sociais, 200.

33 Originado das idéias de Alfredo Rocco.

${ }^{34}$ INCISA, op.cit, pág. 45.

35 Ibid.

${ }^{36} \mathrm{O}$ porta-voz deste movimento era o jornal $O$ Trabalhador, editado por Abel Varzim.

${ }^{37}$ INCISA, Ludovico. op. cit. p. 290.

${ }^{38}$ Para uma análise mais precisa ver http://art.supereva.it/oriadelduce/corporativismo.htm.

${ }^{39}$ HALL, Michael. "Corporativismo e fascismo - as origens das leis trabalhistas brasileiras". In: ARAÚJO, Maria Carneiro (org.). Do corporativismo ao neo-liberalismo. São Paulo: Editorial Boitempo, 2004, p. 13-28.

${ }^{40}$ Ibid, p. 21.

${ }^{41}$ Para uma leitura crítica ver SCHWARZENBERG, Cláudio. El sindicalismo fascista. Milão: Mursia, 1971.

42 VIANNA, Luiz Werneck. Liberalismo e sindicato no Brasil. 2. ed. Rio de Janeiro: Paz e Terra, 1978 (Coleção Estudos Brasileiros). Este autor analisou o Estado que emergiu de 1930, como sendo um 'Estado de compromisso'. 
${ }^{43}$ LUSTOSA, Eduardo M. O corporativismo (1). Sua missão - suas realizações - suas esperanças. A Ordem, ano XVIII, v. 19, p. 89-106, jan.- jun. 1937.

${ }^{44}$ Palavras de Leão XIII. Idem, p. 89.

${ }^{45}$ BRENTANO, Leopoldo Padre. O clero e a ação social. Rio de Janeiro: CNCO, 1942. p.70-71. Edição comemorativa do cinqüentenário da Encíclica Rerum Novarum.

46 Ibid.

${ }^{47}$ Ibid., p. 33.

${ }^{48} \mathrm{Ibid}$

${ }^{49}$ Ibid., p. 34.

${ }^{50}$ Ibid.

${ }^{51}$ Ibid., p. 35.

52 Ibid.

${ }^{53}$ Quadragesimo Anno. Citado por ROMANO, Roberto. Igreja contra Estado. São Paulo: Ed. Kairós, 1979, p. 12.

${ }^{54}$ ROMANO, Roberto. Igreja contra Estado, op.cit, p. 152.

${ }^{55}$ GOMES, Ângela Castro. Burguesia e trabalho. Política e legislação social no Brasil. 19191937. Rio de Janeiro: Ed. Campus, 1979, p. 209.

${ }^{56}$ ROMANO, Roberto. Igreja contra Estado op. cit. p. 152. "Por corporaçōes, a Igreja entende toda a sociedade privada juridicamente constituída e sua utilidade está provada “(...) pela história e pela razão", já que "1- É um fato histórico e indiscutível que nossos antepassados experimentaram durante muito tempo a influência benfazeja das corporações, e que a grande causa do mal estar atual parte da supressão destas mesmas corporaçōes pela Revolução Francesa; 2-É uma lei da natureza freqüentemente relembrada pelos livros santos que os homens colhem preciosas vantagens da sua união: 'o irmão é semelhante a uma cidade fortificada'. Em linguagem corrente dizemos: a união faz a força”. ${ }^{57}$ Ibid., p. 153.

\section{Referências bibliográficas}

ARAUJO, Ângela M e TAPIA, Jorge R. B. Corporativismo e neo-corporativismo: o exame de duas trajetórias. BIB, Rio de Janeiro, n. 32, Segundo semestre de 1991. BRENTANO, Leopoldo Padre. O clero e a ação social. Rio de Janeiro: CINCO, 1942. Edição comemorativa do cinqüentenário da Encíclica Rerum Novarum. CASTILLO, Juan José. El sindicalismo amarillo en España: aportación al estúdio del catolicismo social spañol (1912-1923). Madrid: Edicusa Editorial, 1977. (Cuadernos para el dialogo).

FERRO, Antônio. Salazar, Le Portugal et son chef (précedé d'une note sur I'idée de dictature pour Paul Valéry). Paris: Grasset, 1934

TOPOI, v. 7, n. 13, jul.-dez. 2006, pp. 424-444. 
GOMES, Ângela Castro. Burguesia e trabalho. Política e legislação social no Brasil. 1919-1937. Rio de Janeiro: Ed. Campus, 1934

HALL, Michael "Corporativismo e fascismo- as origens das leis trabalhistas brasileiras!. In: ARAÚJO, Maria Carneiro (org.). Do corporativismo ao neoliberalismos. São Paulo: Editorial Boitempo, 2004.

HOBSBAWN, Eric. A era dos extremos. São Paulo: Paz e Terra, 1997.

INCISA, Ludovico. In: Dicionário de política. Organizado por Norberto Bobbio. Traduzido por Carmem C. Varriale et al. 7 ed. Brasília, DF: UNB, 1995.

LIMA, Alceu Amoroso. Pesten aetatis nostrae laicismum (1932). Pela Ação Católica. Rio de Janeiro. Biblioteca Anchieta, 1935.

LUCENA, Manuel de. A evolução do sistema corporativo português. Lisboa: Perspectivas e Realidades, 1986.

LUSTOSA, Eduardo M. O corporativismo (1). Sua missão - suas realizações suas esperanças. A Ordem, ano XVIII, v. 19, p. 89-106, jan-jun. de 1937.

MONOILESCO, Mihail. O século do corporativismo. Rio de Janeiro: José Olympio, 1938.

MARTINHO, Francisco Carlos Palomanaes. A bem da nação. O sindicalismo português entra a tradição e a modernidade (1933-1940). Rio de Janeiro: Civilização Brasileira/ FAPERJ, 2002

MILER, René Fulop. Leão XIII e o nosso tempo. Potência da Igreja. Poder do mundo. 2. ed. Porto Alegre, 1941.

O'DONNELL, Guillermo. Acerca del 'corporativismo' y la question del Estado. Buenos Aires: Documento Cedeg e Clasco. N. 2, 1982.

PIO XI, papa. Quadragésimo anno - Sobre a restauração e aperfeiçoamento da ordem social. Juiz de Fora: Lar Católico, 1944.

REZOLA, Maria Inácia. O sindicalismo católico no Estado Novo. 1931-1948. Lisboa: Editorial Estampa, 1999.

SALAZAR, Oliveira. Como se levanta um Estado. Lisboa: Golden Books, 1977.

SCHMITTER, Philippe C. Portugal. Do autoritarismo à democracia. Lisboa: Imprensa de Ciências Sociais, 2000.

SCHWARZENBERG, Cláudio. II sindicalismo fascista. Milão: Mursia, 1971.

SOUSA, Jessie Jane Vieira de Sousa. Círculos operários. Igreja Católica e o mundo do trabalho no Brasil. Rio de Janeiro: Editora da UFR, 2002.

STEPEN, A. Estado, corporativismo e autoritarismo. Rio de Janeiro: Paz e Terra, 1980. 
VIANNA, Luiz Werneck. Liberalismo e sindicato no Brasil. 2. ed. Rio de Janeiro: Paz e Terra, 1978. (Coleção Estudos Brasileiros).

VOLOVITH, Marie-Chistine. O le mouvement catholique au Portugal à la fin de la Monarchie Constitucionnale (1891-1913), Paris: Sorbone Nouvelle (Paris III), Tese de Doctorat de 3éme Cycle, 1983.

WIARDA, Howard. Corporativism and development in the iberic-latin world: persistent strains and new variations. The Review of Politics, v. 36, 1974.

\section{Resumo}

$O$ artigo procura, numa perspectiva comparada, analisar as diferenças entre o corporativismo católico e aquelas experiências corporativas estatais que marcaram o cenário mundial, particularmente aquelas vividas em Portugal, Espanha e na Itália no periodo entre as duas grandes guerras mundiais. Para esta análise procuramos demarcar um campo específico na medida em que entendemos que o corporativismo católico não se confunde com o corporativismo estatal, muito embora ambos tenham em comum forte apelo disciplinador assumido pelos setores conservadores quando da emergência da questão social como sendo fundamentalmente uma questão do trabalho. Interessa-nos entender como o corporativismo católico se apresentou no Brasil e quais as suas convergências/divergências com o corporativismo católico presente na Europa no periodo citado. Faz-se necessário ainda compreender os caminhos discursivos através dos quais esta Igreja constrói seu discurso totalizador.

\section{Abstract}

This work analyses in a corporative perspective, the differences between catholic corporativism and state corporative experiences that marked the world scenario throughout the period of the two world wars, particularly in Portugal, Spain an Italy. To realize the investigation a specific area of interest is defined in an attempt not to allow that the catholic corporativism be misinterpreted as state corporativism, although both of them have a strong discipline appeal. The conservative side assumed this appeal during the emergency of the social problem, as a matter of work. It is of paramount importance to understand how the catholic corporativism was displayed in Brazil and which was its connections and divergence with the catholic corporativism present in Europe at the same time. It is necessary yet, to understand the discoursive routes through which the Church built its sole speech. 